\title{
IDENTITY, TERRITORY AND GEOGRAPHY EDUCATION
}

\author{
Péter BAGOLY-SIMÓ \\ Humboldt-Universität zu Berlin, Berlin, Institute of Geography, GERMANY \\ peter.bagoly-simo@geo.hu-berlin.de \\ DOI: http://doi.org/10.23740/TID120185
}

\section{ABSTRACT}

Identity and territory are concepts intimately connected to Regional Geographies. Over the last decades, however, Regional Geographies experienced a certain erosion both within the academic discipline of Geography and school Geography. While Geography traditionally deals with identities from a spatial perspective, there is little information on how school Geography deals under shifting frameworks with both identities and territories. This paper takes a closer look at the state of Regional Geographies against the background of identity and territory in three contexts. Germany stands for a school Geography anchored in a thematic-regional tradition, where national identity plays a secondary role. Also, it represents federal and decentral educational systems. Romania stands not only in an exemplary manner for post-socialist countries. It also exemplifies countries with a school Geography deeply rooted in a regional tradition. Finally, Mexico represents the post-colonial status, with a strong national identity tied to the national Geography. This exploratory study underlines the erosion of Regional Geography in three school Geographies. Also, territory and identity experience other reconfigurations within Geography education based on key concepts and conceptualized against the background of system theory.

\section{INTRODUCTION}

Identity and territory are two concepts connected to school Geographies. Traditionally, school Geographies worked indirectly with identities based on skin color, religion, and language. In doing so, they supported national discourses and contributed to a considerable extent to nationbuilding (Bagoly-Simó, 2008). While General Geography served as grounds to introduce variables identities could rest on (e.g. language or religion), it was Regional Geography that consolidated identities and connected them to territories. Such practices became particularly visible on the national scale.

Regional Geography, however, has experienced a continuous erosion both within the academic discipline of Geography and school Geography. Countries seem to be replacing regional approaches in favor of more thematic ones. Geography education based on key concepts and following system theory seems to work as a catalyst for this process.

This paper briefly explores the state of Regional Geographies against the background of identity and territory in three contexts. Germany stands for a thematic-regional tradition widely disconnected from identities and territories. Romania follows a post-socialist path-dependency 
within a school Geography still conceptualized along Regional Geography. Mexico stands for a post-colonial understanding of a nation in the global context.

\section{GERMANY}

The federal structure of the German educational system leads to multiple conceptualizations of school Geography, and, inherently, curricula. In addition to the 16 federal states, there are various types of secondary schools. Each of these works with specific curricula designed along the needs of future students. In consequence, studies on Geography education in Germany are often limited to the example of selected federal states and types of schools.

Apart from being the federal capital city, Berlin also enjoys the status of an independent federal state and, hence, has the right to design its curricula. Geography is a mandatory subject all through lower secondary education (grades 7-10, students aged 12-17). All types of lower secondary schools share a joint curriculum (SBJW/MBJS, 2015) that recently broke with the path-dependent post-socialist development both on content and conceptual scale. Geography is taught in one weekly hour.

The curricular content of both grades $7 / 8$ and $9 / 10$ contains four thematic areas. During the first two years of lower secondary education, students explore the topics of life in risk areas, migration and population, Earth's diversity, poverty and wealth. For the final two years, the curriculum prescribes the following mandatory topics: handling of resources; climate change and protection as an example for dealing with international conflicts; economic interconnectedness and globalization; Europe in the world. On all content elements, the curriculum remains very open and merely recommends suitable examples to deal with selected topics. What the curriculum, however, omits to prescribe are the spatial examples and regions to be discussed.

The Berlin curriculum breaks with at least two traditional aspects of German school Geography. On the one hand, the current curriculum replaces a regional-thematic approach by a thematic one. In the aftermath of 1969, German school Geography followed a thematic-regional (and in some cases, regional-thematic) approach. This approach linked the continents and regions to selected topics. Brazil, for example, served as an example of the thematic aspect of tropical rain forests and their usage. Africa served as a regional example of poverty, hunger, and diseases (e.g. AIDS). The ambition of the approach was to merely introduce selected topics by the example of specific regions to transfer the content knowledge to other regions in a subsequent step (e.g. tropical rainforests in Africa and Asia or poverty, hunger, and diseases in other developing, but also developed countries). Teachers implementing the Berlin curriculum not only have the chance to select those spatial examples they consider most suitable for the thematic unit; they are even requested to do so. On the other hand, the curriculum reduces subject-specific geographical knowledge to decoding systems. Geography, in the view of the Berlin curriculum, explain human-environment interactions from a systemic perspective. Along with the concept of system, sub-system, process, and structure, scale is one of the central concepts. Thus, scale replaces elements of Regional Geography.

Aspects of territorial identity are missing from the Berlin Geography curriculum for lower secondary education. Also, the Geography of Germany is not part of a specific unit or even a grade course as it is the case in other countries. 
Summing up, the Berlin lower secondary Geography curriculum breaks with its path-dependent development by replacing the regional-thematic approach by a pure thematic one (Figure 1), where teachers are required to pick their regional examples.

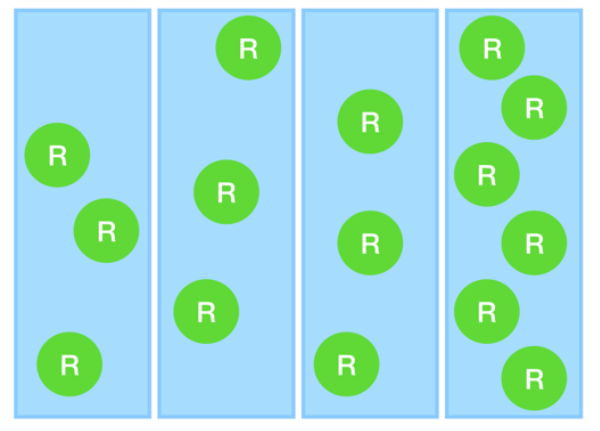

Figure 1: Regional elements in the Berlin Curriculum

(blue: thematic elements, green: Regional Geography)

Source: the author

While Regional Geography as a whole becomes less important for the subject, the concept of scale replaces its former importance. Students are required to work geographically along at a specific scale and even compare different scales. Geography education, however, remains disconnected from spatial identity.

\section{ROMANIA}

Formal education prescribes Geography as a compulsory subject in both primary and secondary education. Lower secondary Geography taught in grades 5-8 (students aged 11-15) falls back on scarce time resources of merely one weekly hour (MECl, 2009). Similar to other former socialist countries, post-socialist transformation continues to shape path-dependent school Geographies in Romania (Bagoly-Simó, 2008). These path-dependencies manifest at both content and conceptual level.

Concerning the content, the curricular architecture of lower secondary Geography prescribes for the fifth-grade elements of General Geography to initiate geographical learning. Students start by addressing the Solar System and its selected elements (e.g. stars, planets, comets) and proceed to work with aspects of spatial orientation and Cartography. Subsequently, Geomorphology, Meteorology, Climatology, Hydrology, Biogeography, and Pedology support students in understanding the basics of Physical Geography. Lastly, Human Geography (Population, Settlement, and Economic Geography) closes the introductory fifth-grade course. The remaining three grades follow a regional approach on the continental and national scale. Sixth and seventh grade Geography explores all continents following a regional approach by the example of selected countries. Elements of fifth-grade General Geography serve as the backbone to every country profile. Finally, the closing course of lower secondary education focuses on the national territory of Romania.

This content structure corresponds to a traditional understanding of Geography. Epistemologically, Romanian school Geography combines elements of General Geography with 
those of Regional Geography (Figure 2). It is the regional aspects that give a face to three of the four years of lower secondary Geography. Students learn about all continents and their home country, Romania. However, it is the General Geography introduced in fifth grade that constitutes the scaffold for every regional example on the continental, sub-continental or national scale. Nevertheless, lower secondary education fails to introduce a specific understanding of Geography that reaches beyond the description on different scales. Despite the regional approach, key concepts, such as scale or region that could work as a conceptual framework for geographical thinking are missing.

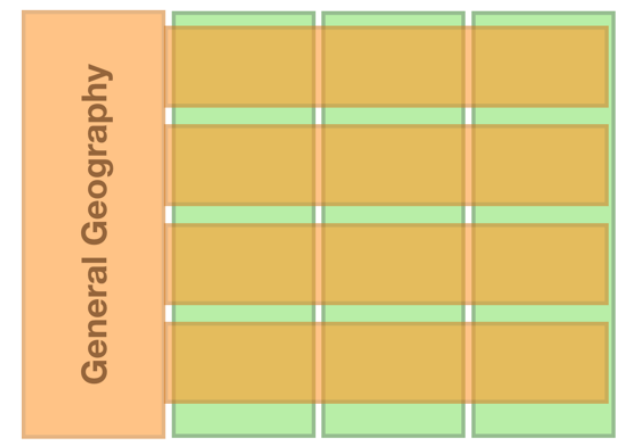

Figure 2: Regional elements in the Romanian Curriculum

(orange: General Geography, green: Regional Geography)

Source: the author

Territorial identity remains essential for Romanian school Geography given its required service to nation-building. In most cases, nation-building happens indirectly by setting the national as the standard scale of description (and rarely even analysis). It is the sections on population structure that outline territorial identities based on language, religion, and ethnicity. Differences between nation-building strategies within the Geography of Romania (eighth grade) and other multinational states are awaiting exploration.

Summing up, Romanian lower secondary Geography relies strongly on regions and a regional approach. However, it lacks any conceptual framework that places the region and Regional Geographies within both epistemology and content. The current curricular architecture is a result of a path-dependent development linking back to socialism. While the economy no longer serves as the central category of regionalization (command economies vs. market economies), nationstates remain the essential means to discuss the world. This approach leads to robust nationbuilding employing territorial identity in the case of the Geography of Romania (eighth grade).

\section{MEXICO}

Most of Geography education in Mexico happens in primary school (grade 1-6, students aged 613). The first grade of lower secondary education prescribes the final mandatory Geography course of Mexican formal education, Geography of Mexico and the World (SEP, 2011). This final course reflects current discourses on post-colonial Geographies across Latin America by introducing a comparative perspective in five weekly hours. 
Geography of Mexico and the World entails five thematic units. Students start their secondary training in Geography by focusing on space and maps. While working on the next three chapters, they focus on the natural environment, social and cultural aspects, and economic development. Finally, the concluding chapter turns students' attention to the topics of quality of life, environment, and risk prevention. Each thematic aspect is required to be reflected on both the global and the national scale.

Mexican lower secondary Geography follows a thematic approach that relies on two central concepts. On the one hand, the curriculum rests on the central concept of geographical space. In its Mexican conceptualization, space entails natural, social, cultural, economic, and political components. In doing so, lower secondary Geography adopts a systemic perspective that is highly compatible with sustainable development (Bagoly-Simó, 2014). On the other hand, scale plays an essential role in Geography education. During primary education, students first focus on the local scale (first and second grade), proceed to the federal state (third grade), dedicate attention to the national scale (fourth grade), turn to the continental scale (fifth grade), and, finally, deal with the global scale (sixth grade). The only lower secondary course, which at the same time is the concluding Geography course of formal education, works with comparison and contrast on two scales, namely the national (Mexico) and the global (world). Regional Geography, thus, appears coded in the concept of scale (Figure 3).

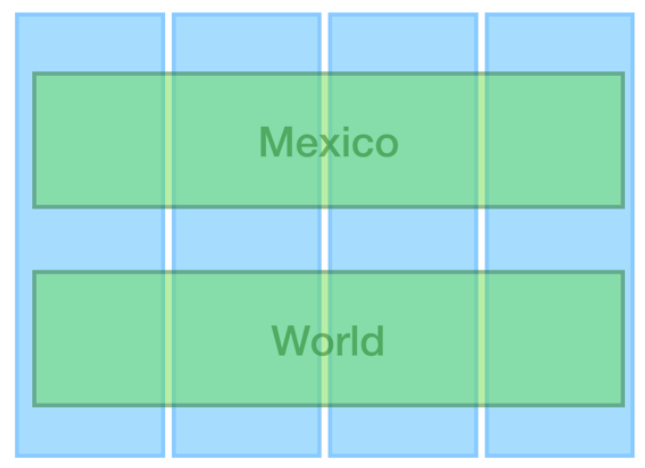

Figure 3: Regional elements in the Mexican Curriculum (blue: thematic elements, green: Regional Geography) Source: the author

Thoughts on territorial identity seem to emerge from a post-colonial understanding of belonging. Lower secondary Geography presents its content in a contrastive and comparative manner on the national and global scale. Every process, every geographical structure, each stakeholder is subject to comparison. Pointing out the particularities of the Mexican space and population becomes one of the central objectives of the concluding Geography course of formal education. Also, the national curriculum opens the possibility to study History and Geography of the Federal State as an elective subject. This subject adds a regional scale by pointing out particularities of the state and sub-state scale. Mexican lower secondary Geography, thus, seems to enforce regional identities as part of a robust national identity within the framework of the post-colonial perspective.

Summing up, Mexican lower secondary education follows a thematic approach based on the two central geographical concepts of space and scale. The concept of scale and selected spatial 
examples replace traditional Regional Geography. Understanding the geographical space is at the heart of the concluding course of formal training in Geography. The contrastive and comparative scalarity inherent to Geography of Mexico and the World contributes significantly to nation-building.

\section{CONCLUSIONS}

The preliminary results of this exploratory overview showed that lower secondary Geography deals with the concepts of identity and territory in different manners when it comes to Regional Geography. On the one hand, Regional Geography itself seems to play-except for former socialist countries-a secondary role for school Geography. The concept of scale seems to have replaced broader understandings and concepts of Regional Geographies. On the other hand, identity and territory seem tied to the national scale. Their contribution to nation-building happens by focusing on the national scale and the national state itself, as shown in the case of Romania. An alternative contribution happens through comparison and contrast with spatial units on another scale (e.g. global scale), as experienced in the Mexican case. Also, identity and territory seem to be less central of concepts in school Geographies following a thematic approach as opposed to those organized on the grounds of a regional approach.

The three case studies presented in this paper raise many questions. What are the specific understandings of identities in school Geography? What concepts of territory do school Geographies teach? How do identities and territories interlace? What is their connection to Regional Geographies, or, in other words, how do they manifest within different approaches and epistemologies? Future work should explore these questions.

\section{REFERENCES}

BAGOLY-SIMÓ, P. (2008). Földrajzdidaktikai kutatások [Research in Geography Education]. Bucharest: Editura Didactică și Pedagogică.

BAGOLY-SIMÓ, P. (2014). Tracing Sustainability: Concepts of Sustainable Development and Education for Sustainable Development in Lower Secondary Geography Curricula of International Selection. International Research in Geographical and Environmental Education, 23(2): 126-141. DOI: 10.1080/10382046.2014.908525

MECI (MINISTERUL EDUCAȚIEI, CERCETĂRII ȘI INOVAȚIEI) [NATIONAL MINISTRY OF EDUCATION, RESEARCH AND INNOVATION]. (2009). Programe școlare. Geografie. Clasele a V-a-a VIII-a [School Curricula. Geography. Grades 5-8]. Bucharest: MECI.

SBJW/MBJS (SENATSVERWALTUNG FÜR BILDUNG, JUGEND UND WISSENSCHAFT/MINISTERIUM FÜR BILDUNG, JUGEND UND SPORT) [STATE SENATE FOR EDUCATION, YOUTH AND SCIENCE/MINISTRY OF EDUCATION, YOUTH AND SPORT]. (2015). Rahmenlehrplan. Teil C, Geografie, Jahrgangsstufen 7-10 [Curriculum. Part C, Geography, Grades 7-10]. Berlin/Potsdam: SBJW/MBJS.

SEP (SECRETARÍA DE EDUCACIÓN PÚBLICA) [SECRETARY OF PUBLIC EDUCATION]. (2011). Programas de Estudio 2011. Guía para el maestro. Educación Básica. Secundaria. Geografía de México y del Mundo [Study Programs 2011. Teachers' Guidebook. Mandatory Education. Secondary Education. Geography of Mexico and the World]. Mexico City: SEP. 